\title{
https://doi.org/10.46344/JBINO.2020.v09i5b.02
}

\section{LITERATURE STUDY OF CHARAKOKTA VARNYA AND VISHGHNA MAHAKASHAY- A REVIEW}

\author{
Dr. R .Sneha R. Mujumdar
}

Professor, Dravyaguna vidgyan , A.R.A.C ,Manchi Hill ,District Sangamner , Maharashtra

\begin{abstract}
The cosmetics are the utility products used extensively throughout the world for maintaining and improving general appearance of face and other parts of the body. There are immense opportunities to use herbal ingredients in the cosmetics in accordance with the principles of Ayurvedic medicine. The aim of this study was to critically evaluate the herbs mentioned in Varnya Maha Kashaya for the maintenance of the complexion of skin. Ayurvedic texts, journals and other research articles were reviewed. The great text in Ayurveda, the Charaka Samhita, stated a group of ten medicinal plants known as Varnya Maha Kashaya that can be used to obtain glowing complexion. It includes Shveta Candana (Santalum album), Nagkeshara (Mesua ferra), Padmaka (Prunus cerasoides), Ushera (Vetiveria zizanioides), Madhuka (Glycyrrhiza glabra), Manjistha (Rubia cordifolia), Shariva (Hemidesmus indicus), Payasya (Ipomoea digitata), Sita (white variety of Cynodon dactylon) and Lata (green variety of Cynodon dactylon ).
\end{abstract}

Keywords: Charakokta, Mahakashay etc. 


\section{Introduction}

Danshtra chikitsa, Agad tantra and Vishagarvairodhik prashaman are synonym of each other. Danshtra chikitsa is the sixth branch of Ayurveda which mainly deals with agada i.e. the medicine with antipoisonous effects. [1] Visha means the dravya which causes vishaad (sorrow or depression) is known as visha. [2] Laghu, ruksha, aashu, vishad, vyavayi, tikshna, vikaashi, sookshma, ushna, anirdeshyarasa are the ten properties of poisonous drugs. [3] Drugs which act against toxic effect of substances are called as vishghna. [4] Acharya Charak has described vishaghna mahakashaya which includes ten vishghna drugs. [5] It includes haridra (Curcuma longa), manjishtha (Rubia cordifolia), Suvaha (Pluchea lanceolata), sukshama ela (Elettaria cardamomum), paalindi (Operculina turpethum), chandan (Santalum album), kataka (Strychnos potatorum), shirisha (Albizzia lebbeck), sinduvara (Vitex negundo), shleshmataka (Cordia dichotoma).

Rubiacordifolia Rubia cordifolia show potent antioxidant activity against lead nitrate and radiation induced toxicity. According to Bhava Prakash, rubia cordifolia is able to bind itself with amavisha (free radicals) and garavisha toxins which cause inflammation, skin disease, and ulcers and others problems. Alizarin Biomarker of rubia cordifolia is responsible for Antigenotoxic activities. A balanced combination of Soma (cooling) and Agni (heat) found in Rubia cordifolia. Agni allows the herb to penetrate into the cellular level of tissue and Soma helps to soak up toxins and neutralize them. Pluchea lanceolata It is useful in the treatment of spider bite. Pluchea lanceolata having properties to protect against Benzo(a) pyrene induced renal toxicity and loss of DNA integrity. Elettaria Cardamomum Cardamom, it is known as "Queen of Spices". The aqueous cardamom suspension can enhance detoxifying enzyme (GST activity) and decrease peroxidation of lipid. Operculina terpethum hydroalcoholic extract of Operculina turpethum, is highly significant for management of hepatotoxicity and diminishes extension of liver injury. Santalum album The DNA damaging activity of sandalwood oil in Bacillus subtilis was studied and was found to be nongenotoxic. Similarly, sandalwood oilinduced inhibition of $B$. subtilis showed it to be non-genotoxic. Strychnospotatorum Strychnos potatorum is also known as Clearing nut Tree. Seeds of Strychnos potatorum are used in ayurvedic medicine as well as water purifying agent. Albizzialebbeck Shirisha is the best drug / drug of choice of poisoning (ch.su. 25/40). Ethanolic Extract of leaves of Albizzia lebbeck show remarkable effect against paracetamol induced hepatotoxicity in rat (Devendra et al. 2008) and Ethanolic Extract of bark of Albizzia lebbeck show significant result in carbon tetra chloride induced hepatotoxicity in rat (tushar et al.2010). Vitexnegundo Leaf extract of Vitexnegundo Linn. Shows significant result in Adriamycin induced toxicity in embryo. It reduces adverse effect of Adriamycin. 
DISCUSSION Most drug of Vishaghna mahakashaya having property of vishaghna. Eg Haridra (Dhanwantari Nighantu), Manjishtha (Bhav prakash Nighantu, Dhanwantari Nighantu, Kaideva Nighantu, Raj Nighantu), Suvaha (Bhava praksh Nighantu), Chandan (Bhava praksh Nighantu), Katak (Dhanwantari NighantuKaideva Nighantu), Shirisha (Charak Samhita-Bhava praksh Nighantu Kaideva Nighantu), Shleshmatak (Bhava praksh Nighantu). Vishaghna mahakashaya dravya shows the antitoxic effect by neutralizing toxin, denaturizing toxin and helps to release toxin outside from the body at the cellular level.

CONCLUSION By this compiled critical review work, it is concluded that vishaghna mahakashya is easy available multiherbal potent preparation for prescribing drug as well as various research ways e.g. To treat of all types of poisoning, Gara visha, Dushi visha, Snake bite, Scorpian bite, rat bite, Sting, Chronic cumulative biochemical toxicity, drug toxicity (ADRS/ Side effect) and substance abuse toxicity. Now we are able to justify the claims of Ayurveda science in the field of toxicological studies on the contemporary scenario.

\section{REFERENCES:}

Ashtangahradayam, Kaviraj atridev gupta, Chaukhamba Sanskrit Sansthan Varanasi, edition 13, sutasthana, chapter, 1/5.

2. Sushruta Samhita, Kaviraj ambikadatta shastri commentary, Chaukhamba Sanskrit Sansthan Varanasi, edition 13, kalpasthana, chapter, 3/21.
3. Charak Samhita, Kashinath shastri commentary, Chaukhamba Sanskrit Sansthan Varanasi, edition 6, Chikitsasthana, chapter, 23/24.

\section{Charak Samhita, Kashinath shastri} commentary, Chaukhamba Sanskrit Sansthan Varanasi, edition 6, sutraasthana, chapter, 4: 59.

5. Charak Samhita, Kashinath shastri commentary, Chaukhamba Sanskrit Sansthan Varanasi, edition 6, sutraasthana, chapter, 4/16.

6. Shama p v, dravyaguna vigyan vol. 2 (vegetable drugs), chaukhamba bharati academy Varanasi reprint edition, 2006.

7. Sason Rajveer, Anita sharma, Neelam arya IJAPR, may 2016; 14(5): 66.

8. Shama $\mathbf{p} \mathbf{v}$, dravyaguna vigyan vol. 2 (vegetable drugs), chaukhamba bharati academy Varanasi reprint edition, 2006.

9. Ingle N, Ojha N, Kumar A Critical Analysis of Charakokta Mahakashaya in the Management of Respiratory Allergic Disorder JHomeop Ayurv Med, 2013; 2: 127. Doi:10_4172/2167-1206_1000127.

10. Phytopharmacological overview on „Kushthaghna mahakashaya World Journal Of Pharmacy And Pharmaceutical Sciences, 2015; 4(1): 306-333.

11. Dr. Anjali Sheok and Clinical efficacy of Ashwagandharishta in Madatyaya w.s.r. to alcoholism P.G Department of Agad tantra, 2010- 11;87-88.

12. Dr. Anjali Sheok and Clinical efficacy of Ashwagandharishta in Madatyaya w.s.r. to 
alcoholism P.G Department of Agad tantra, 2010- 11; 95-96.

13. Dr. Anjali Sheok and Clinical efficacy of Ashwagandharishta in Madatyaya w.s.r. to alcoholism P.G Department of Agad tantra, 2010; 11: 121-122.

14. Savita B. Chougule Vishaghna Mahakashaya - A Review AAMJ, 2015; $1(4)$.

15. Dr. Anjali Sheok and Clinical efficacy of Ashwagandharishta in Madatyaya w.s.r. to alcoholism P.G Department of Agad tantra, 2010; 11: 106-07.

16. Pandey, Gyanendra Dravyaguna Vigyana Chaukhamba, Varanasi, 2004; 2: 205-07.

17. Pandey, Gyanendra Dravyaguna Vigyana, Chaukhamba, Varanasi, 2004; 2: 481-83.

18. Dravyaguna vidnyan, Part-Il, by Priyavat Sharma, Chaukhambha Bharati academy, Reprint, 2005; 66-69.

19. Pandey, Gyanen, Dravyaguna Vigyana, Chaukhamba, Varanasi, 2004; 2: 497-99.

20. Sushruta samhita, part-l, by Kaviraj Ambikadatta Shastri, Chaukhambha Sanskrit Sansthan Varanasi, 13th edition, Kalpasthana, ch., 5/61,62,74.

21. Sushruta samhita, part-l, by Kaviraj Ambikadatta Shastri, Chaukhambha Sanskrit Sansthan Varanasi, 13th edition, Kalpasthana, ch., 8/48-52.

22. Sushruta samhita, part-l, by Kaviraj Ambikadatta Shastri, Chaukhambha
Sanskrit Sansthan Varanasi, 13th edition, Kalpasthana, ch., 7/39.

23. Ashtangahrdayam, by Kaviraj Atridev Gupta, Chaukhambha Sanskrit Sansthan Varanasi, 13th edn, Uttersthana, ch., 37/70, 71.

24. Sushruta samhita, part-I, by Kaviraj Ambikadatta Shastri, Chaukhambha Sanskrit Sansthan Varanasi, Thirteenth edition, Kalpasthana, ch., 5/61,62,68,76.

25. Sushruta samhita, part-l, by Kaviraj Ambikadatta Shastri, Chaukhambha Sanskrit Sansthan Varanasi, 13th edition, Kalpasthana,ch., 6/3,8.

26. Ashtangahrdayam, by Kaviraj Atridev Gupta, Chaukhambha Sanskrit Sansthan Varanasi, 13th edition, Uttersthana, ch., $37 / 71$. 